四サイクル中速 V 形ディーゼル機関最適化計画のための 機関質量におよぼす主要目の影響度解析と簡易機関質量予測式(続報)*

\author{
小山田哲也*1, 和 栗 雄太郎*2
}

平 山義 則*3, 生田宏*1

\title{
Analyses of the Influence Degree of Principal Particulars \\ on the Engine-Mass and Simplified Engine-Mass Estimation \\ Method for Optimum Planning on the Four-Stroke Cycle, Medium Speed, V-Type Diesel Engines (Supplemental Report)
}

Tetsuya OYAMADA*4, Yutaro WAKURI,

Yoshinori HIRAYAMA and Hiroshi IKUTA

${ }^{* 4}$ Kyushu Kyoritsu University, Department of Mechanical Engineering,

1-8 Jiyugaoka, Yahatanisi-ku, Kitakyushu-shi, Fukuoka, 807-8585 Japan

When developing a new four-stroke cycle, medium speed, $\mathrm{V}$-type diesel engine, it is desirable to establish suitable target of the engine-mass in early stage of initial planning. Since the engine-mass is closely related to the engine manufacturing cost. By the way, some of the principal particulars to be selected in this stage side by side have the great influence on the engine-mass. So if the influence degree of each principal particular is cleared in advance by analyzing, it will be possible to select the most suitable principal particulars rationally and efficiently. The authors developed mass estimation and evaluation simulating method for optimum planning on the same type above-mentioned engine, and reported before. This time, the authors present on the results of analyses of the influence degree of principal particulars on the engine-mass using the above-mentioned method and the simplified engine-mass estimation method applicated with these above results of analyses as a supplemental report.

Key Words: V-Type Diesel Engine, Engine Mass, Influence Degree, Principal Particulars, Simplified Engine-Mass Estimation Method

\section{1. ま え がき}

新しい四サイクル中速 V 形ディーゼル機関を開発 する際には，その最重要要目の一つである製造コスト の予測の目安になる機関総質量や出力当たり質量の適 切な目標値を初期計画の段階で設定することが望まし い. ところで, この際に並行して選定するいくつかの 主要目にはこれらの機関質量におよぼす影響が大きい ものがあるので, これらの各主要目が機関質量におよ ぼす影響度についてあらかじめ解析して明らかにして おけば, 機関の最適化計画に役立つ適切な主要目を合 理的に，かつ効率的に選定することができる.

著者らは前に, この形式機関の最適化計画のための 質量予測・評価シミュレーション手法を開発して報告

* 原稿受付 2003 年 8 月 4 日.

*1 正員, 九州共立大学工学部 (807-8585 北九州市八幡西区 自由ヶ丘 1-8).

*2 正員, 九州大学名誉教授(⑧10-0053 福岡市中央区鳥飼 16-45).

*3 正員, 北九州市立大学国際環境工学部( 808-0135 北九州 市若松区ひびきの 1-1)
した(1). 今回はその続報として, 本手法を用いて行っ た各主要目の機関質量におよぼす影響度解析と,また この成果を応用して構築した簡易機関質量予測式につ いて報告する。なお，著者らは以前に同様な考え方に 基づく二サイクル低速クロスヘッド形ディーゼル機関 の質量におよぼす主要目の影響度解析についても報告 したので(2)(3), 両機関の解析結果の比較も示した.

\section{2. 影響度解析の対象とした機関主要目}

著者らのこれまでの研究で, 機関質量におよほす影 響度が比較的大きい機関主要目はシリンダ内径, ピス トン行程, 回転数, シリンダ数, 最高圧力, 正味平均有 効圧力, 連かん比などであることを明らかにしてい

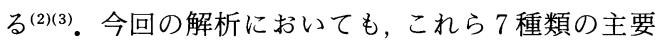
目を対象としてとりあげることにした. ところで, こ れらの 7 種類の主要目のおのおのが機関のどのような 主要部品の寸法や質量に関連をもつものか, 具体的な 例の一部を参考資料 (1) より抜粋して表 1 に示す.

なお，本論文において “機関総質量” とは機関装備 の補機類の質量は含み,ただし機関内の水や潤滑油な どの質量は含まない, いわゆる全備乾燥機関質量を意 
Table 1 Major components and related principal particulars

\begin{tabular}{|c|c|c|c|c|c|c|c|c|}
\hline \multirow{2}{*}{ No. } & \multirow{2}{*}{ Major components } & \multicolumn{7}{|c|}{ Related Particulars } \\
\hline & & $D$ & $S$ & $n$ & $z$ & $P_{m e}$ & $P_{\text {max }}$ & $\lambda$ \\
\hline 1 & Frame body & O & O & & 0 & & 0 & 0 \\
\hline 2 & Cylinder cover assembly & 0 & & & 0 & & 0 & \\
\hline 3 & Crankshaft assembly & 0 & O & & 0 & O & 0 & \\
\hline 4 & Fly wheel & 0 & 0 & 0 & 0 & 0 & & \\
\hline 5 & Connecting rod assembly & 0 & $\mathrm{O}$ & O & 0 & & 0 & 0 \\
\hline$s$ & s & \multicolumn{7}{|c|}{ s } \\
\hline 18 & Oil pan assembly & 0 & $\mathrm{O}$ & & $\mathrm{O}$ & & & \\
\hline 19 & Lubricating oil pumb & 0 & 0 & 0 & $\mathrm{O}$ & $\mathrm{O}$ & & \\
\hline 20 & Intake pipe & 0 & O & 0 & $\mathrm{O}$ & 0 & & \\
\hline$s$ & $s$ & \multicolumn{7}{|c|}{$s$} \\
\hline 31 & Thrust bearing & 0 & 0 & 0 & $\mathrm{O}$ & 0 & & \\
\hline 32 & $\begin{array}{l}\text { Lubricating oil pump driving } \\
\text { gear }\end{array}$ & O & $\mathrm{O}$ & 0 & 0 & 0 & & \\
\hline
\end{tabular}

味するものとし，“出力当たり質量”とは機関総質量 を機関出力で除した值を指すものとする．また，単に “機関質量”と記述した場合は,これらの両質量を総 合して意味するものとする.

\section{3. 機関質量におよぼす主要目の影響度解析}

\section{$3 \cdot 1$ 解析の対象としてとりあげたモデル機関}

解析の対象としてとりあげたモデル機関には, 現在世 界の各メーカで生産されている陸・舶・産業用四サイ クル中速 $\mathrm{V}$ 形ディーゼル機関の製造実績と仕様を参 考にして表 2 に示す 3 機種の想定機関を設定した(1). なお, シリンダ数についてはこれらの機関について数 多くの製造実績がある 12 シリンダを代表的にとりあ げた。これらのモデル機関の呼称形式については, 最 初に示した 12 はシリンダ数を示しており, その次の アルファベットは機関の機種名を表し，それに続く数 字はシリンダ内径を $\mathrm{mm}$ 単位で示している.

$3 \cdot 2$ 解析の進め方と午の評価 前述の 7 種類の 主要目について, 各モデル機関のそれぞれの主要目を 独立して $\pm 50 \%$ の範囲で変化させ，その場合の機関総 質量と出力当たり質量を予測計算して, その該当主要 目の機関質量にたいする影響度の大きさを解析した。 この各主要目の変化範囲土50\%は，前述した 3 機種の モデル機関の各シリンダ内径 $D$ の相互間の寸法比率 を参考にして決めたものである。なお，機関総質量と 出力当たり質量の予測計算には著者らが前に開発した 四サイクル中速 $\mathrm{V}$ 形ディーゼル機関の質量予測・評 価シミュレーション手法を用いた(1).

各主要目の土50\%の範囲での変化については, 各モ
Table 2 The model engines selected for analyses of the influence degree of principal particulars on the engine mass

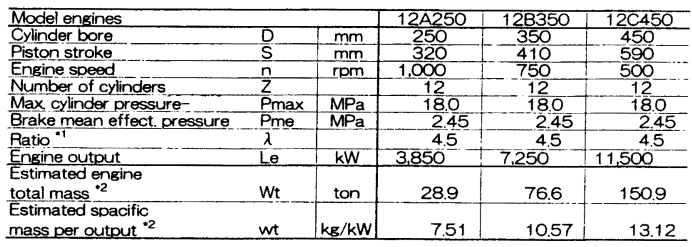

mass per output *2

(Note) *1: Ratio between connecting rod length and crank radius : Estimated engine mass by the engine mass estimation and evaluation
simulating method.

デル機関の該当主要目を基準として, 0.5,0.75, 1.0, 1.25 および 1.5 倍と 5 段階に変化させ，これらのおの おののケースで予測計算した機関質量についてはそれ ぞれのモデル機関の機関質量を基準としてその比率で 評価した。ただ、シリンダ数についてはこのような変 化は適当ではないので，土50\%の範囲のなかで 6,8 , 14 および 18 シリンダの 4 ケースについて機関質量 の予測計算を行った。

これらの予測計算結果を各主要目のモデル機関に対 する比率で整理して滑らかな曲線で結べば，この曲線 は各主要目の機関質量におよぼす影響度を目に見える 形で示すことになる．そこでこの曲線の傾向を指数関 数曲線を用いて近似することにすれば，その関数の乗 べき数の大きさで影響度を定量的に評価できることに なる。

$3 \cdot 2 \cdot 1$ 機関総質量におよぼす主要目の影響度の評 価いまそそぞれの主要目が機関総質量におよぼ す影響度を次式で示す指数関数を用いて近似し，その 乗べき数 $\alpha \sim \eta$ の值で定量的に影響度を評価する.

$$
\begin{aligned}
& \left(W_{t-D} / W_{t-o}\right)=R(D)^{\alpha} \\
& \left(W_{t-s} / W_{t-o}\right)=R(S)^{\beta} \\
& \left(W_{t-n} / W_{t-o}\right)=R(n)^{\gamma} \\
& \left(W_{t-z} / W_{t-o}\right)=R(Z)^{\delta} \\
& \left(W_{t-\mathrm{P} \max } / W_{t-o}\right)=R\left(P_{\max }\right)^{\varepsilon} \\
& \left(W_{t-\text { Pme }} / W_{t-o}\right)=R\left(P_{m e}\right)^{\zeta} \\
& \left(W_{t-\lambda} / W_{t-o}\right)=R(\lambda)^{\eta}
\end{aligned}
$$

ただし，

$$
\begin{aligned}
& R(D)^{\alpha}=\left(D / D_{o}\right)^{\alpha}, R(S)^{\beta} \\
& \quad=\left(S / S_{o}\right)^{\beta}, \cdots, R(\lambda)^{\eta}=\left(\lambda / \lambda_{o}\right)^{\eta}
\end{aligned}
$$

ここに,

$\mathrm{W}_{t}$ : 機関総質量 $(\mathrm{t})$

$D ：$ シリンダ内径 $(\mathrm{mm})$,

$S:$ ピストン行程 $(\mathrm{mm})$ 
$n:$ 回転数 $(\mathrm{rpm})$

$Z:$ シリンダ数

$P_{\max }:$ 最高压力 $(\mathrm{MPa})$

$P_{m e}:$ 正味平均有効圧力 $(\mathrm{MPa})$

$\lambda:$ 連かん比

添 字

$o$ : 基準としたモデル機関

をそれぞれ示す。

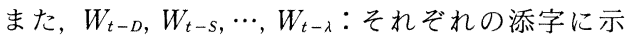
す当該主要目が変化したときの機関総質量を意味す る.

$3 \cdot 2 \cdot 2$ 出力当たり質量におよぼす主要目の影響度 の評価 $3 \cdot 2 \cdot 1$ 項と同様の考え方で, 次式で示す指 数関数の乗べき数 $\alpha^{\prime} \sim \eta^{\prime}$ の值で定量的に影響度を評 価する。

$$
\begin{aligned}
& \left(w_{t-D} / w_{t-o}\right)=R(D)^{a^{\prime}} \\
& \left(w_{t-s} / w_{t-o}\right)=R(S)^{\beta^{\prime}} \\
& \left(w_{t-n} / w_{t-o}\right)=R(n)^{\gamma^{\prime}} \\
& \left(w_{t-z} / w_{t-o}\right)=R(Z)^{\delta^{\prime}} \\
& \left(w_{t-P \max } / w_{t-o}\right)=R\left(P_{\max }\right)^{\varepsilon^{\prime}} \\
& \left(w_{t-P \operatorname{me}} / w_{t-o}\right)=R\left(P_{\operatorname{me}}\right)^{5^{\prime}} \\
& \left(w_{t-\lambda} / w_{t-o}\right)=R(\lambda)^{\eta^{\prime}}
\end{aligned}
$$

ただし，

$$
\begin{aligned}
& \quad R(D)^{\alpha^{\prime}}=\left(D / D_{o}\right)^{\alpha^{\prime}}, R(S)^{\beta^{\prime}}=\left(S / S_{o}\right)^{\beta^{\prime}}, \\
& \quad \cdots, R(\lambda)^{\eta^{\prime}}=\left(\lambda / \lambda_{o}\right)^{\eta^{\prime}} \cdots \cdots \cdots \cdots \cdots \cdots \cdots \cdots \\
& \text { ここに } \\
& w_{t} \text { : 出力当たり質量 }(\mathrm{kg} / \mathrm{kW})
\end{aligned}
$$

添 字

$$
o \text { : 基準としたモデル機関 }
$$

を示す。

また, $w_{t-D}, w_{t-s}, \cdots, w_{t-\lambda}$ : それぞれの添字に示す 当該主要目が変化したときの出力当たり質量を意味す る.

\section{$3 \cdot 3$ 主要目の機関質量におよぼす影響度解析の結}

果 前述の 7 種類の主要目について, 当該主要目 を土50\%の範囲で変化させた場合の機関質量を,これ も前述の四サイクル中速 V 形ディーゼル機関の質量

\begin{tabular}{|c|c|c|c|c|c|c|}
\hline \multicolumn{2}{|c|}{$\begin{array}{l}\text { Ratio of principal } \\
\text { particulars }\end{array}$} & 0.50 & 075 & \begin{tabular}{|c|c|} 
Model engine \\
10
\end{tabular} & 125 & 150 \\
\hline \multirow{5}{*}{$\begin{array}{l}\text { Cylinder bore } \\
D[\mathrm{~mm}]\end{array}$} & D & 175 & 262.5 & 350 & 437.5 & 525 \\
\hline & Le & 1.812 .5 & 4.078 .1 & 7.250 & 11.328 .1 & 16.312 .5 \\
\hline & Wt & 15.2 & 38.6 & 76.6 & 132.3 & 209.0 \\
\hline & $w t$ & $\begin{array}{l}(0.198) \\
8.38\end{array}$ & $\begin{array}{c}(0.504) \\
9.46\end{array}$ & $\begin{array}{l}(1.0) \\
10.57\end{array}$ & $\begin{array}{c}(1.727) \\
1169\end{array}$ & $\begin{array}{c}(2.728) \\
1282\end{array}$ \\
\hline & & (0.793) & $(0.895)$ & $(1.0)$ & $(1.106)$ & (1.213) \\
\hline \multirow{5}{*}{$\begin{array}{l}\text { Piston stroke } \\
S[\mathrm{~mm}]\end{array}$} & s & 205 & 307.5 & 410 & 512.5 & 615 \\
\hline & Le & 3.625 & 5.437 .5 & 7.250 & $9,062.5$ & $10,875.0$ \\
\hline & Wt & 57.5 & 66.6 & 76.6 & 87.1 & 97.9 \\
\hline & wt & 15.86 & 12.25 & 10.57 & 9.62 & $\begin{array}{l}(1.278) \\
9.01\end{array}$ \\
\hline & & $(1.500)$ & $(1.159)$ & $(1.0)$ & $(0.910)$ & $(0.852)$ \\
\hline
\end{tabular}
予測・評価シミュレーション手法を用いて予測計算し た. 次に, これらの予測計算で求めた各機関質量をモ デル機関の質量に対する比率として整理した。これら の解析結果を，モデル機関 12 B 350 形のシリンダ内径 $D$ とピストン行程 $S$ の場合を例にとって表 3 に示す. また，表 3 に示したような各モデル機関の質量に対す る比率と, 前述の指数関数を用いてこれらの比率の傾 向を近似した曲線について, 図 1 に機関総質量の場合
Table 3 Examples of the influence degree analyses of Principal Particulars on the mass of model engine 12B350 Type

\begin{tabular}{|c|c|c|c|c|}
\hline Model engines & $12 \mathrm{~A} 250$ & $12 \mathrm{~B} 35 \mathrm{O}$ & $12 C 450$ & $\begin{array}{c}\text { Reference engine } \\
\text { GUEC6OLS* }\end{array}$ \\
\hline (D) & 0.32 & 0.41 & 0.38 & 0 \\
\hline (S) & -0.60 & -0.49 & -0.45 & 0 \\
\hline (n) & -0.75 & -0.84 & -0.88 & -0.89 \\
\hline (z) & -0.05 & -0.05 & -0.08 & -0.14 \\
\hline$\xi^{\prime} \quad(P \max )$ & 0.45 & 0.50 & 0.53 & 0.62 \\
\hline (Pme) & -0.63 & -0.73 & -0.73 & -0.76 \\
\hline$(\lambda)$ & 0.20 & 0.20 & 0.22 & 0.22 \\
\hline
\end{tabular}

(Note) Le : Ensine output [kW], Wt: Estimated engine total mass $[t]$,

Table 4 The influence degree of principal particulars on the total engine mass

\begin{tabular}{l||c|c|c|c}
\hline Model engines & $12 \mathrm{~A} 250$ & $12 \mathrm{B3} 50$ & $12 \mathrm{C} 450$ & $\begin{array}{c}\text { Reference engine } \\
\text { 6UEC6OLS* }\end{array}$ \\
\hline \hline$\alpha(\mathrm{D})$ & 2.32 & 2.41 & 2.38 & 2.0 \\
\hline$\beta(\mathrm{S})$ & 0.40 & 0.51 & 0.55 & 1.0 \\
\hline$\gamma(\mathrm{n})$ & 0.25 & 0.16 & 0.12 & 0.11 \\
\hline$\delta(z)$ & 1.04 & 0.95 & 0.92 & 0.86 \\
\hline$\xi(\mathrm{Pma} x)$ & 0.45 & 0.50 & 0.53 & 0.62 \\
\hline$\varepsilon(\mathrm{Pme})$ & 0.37 & 0.27 & 0.27 & 0.24 \\
\hline$\eta(\lambda)$ & 0.20 & 0.20 & 0.22 & 0.22 \\
\hline
\end{tabular}

(Note) 1.The influence degree is shown on value with an exponential form of each particular ratio.

2.*:Two-stroke cycle, low speed, crosshead type diesel engine.

Table 5 The influence degree of principal particulars on the specific mass per output

(Note) 1. The influence degree is shown on value with an exponential form of particular ratio.

2.*:Two-stroke cycle, low speed, crosshead type diesel engine.

を, また図 2 に出力当たり質量の場合をとってそれぞ れに示す。これらの各図からおのおののモデル機関の 質量に対する比率の変化の傾向を, 指数関数を用いた 曲線でほぼ近似できることを確かめることができた。 また, 各主要目が機関総質量と出力当たり質量におよ ぼす影響度の大きさを，それぞれ定量的に評価できる 指数関数の乗べき数について表 4 と表 5 に整理して示 す.これらの解析結果から, 以下のことがわかる. $3 \cdot 3 \cdot 1$ 機関総質量におよほす主要目の影響度 各モデル機関とも図 1 と表 4 からシリンダ内径 $D$ の影響度が卓越して大きく, 次いで大きいほうからシ 


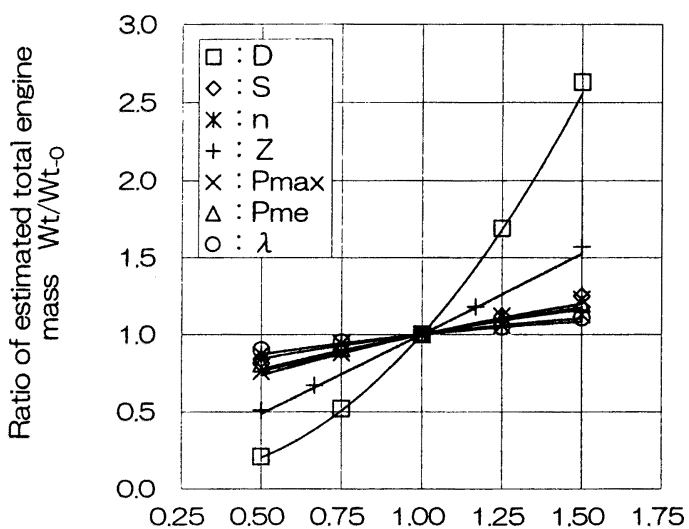

Ratio of each principal particular

(a) The influence degree of principal particulars on the total engine mass (12 A 250 type)

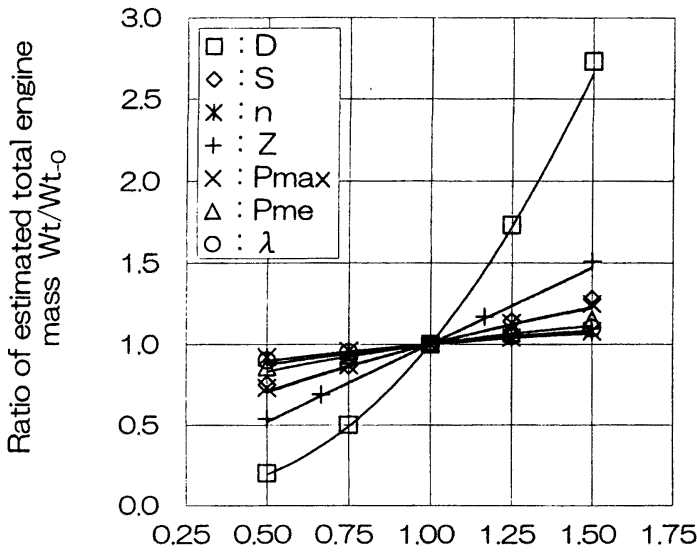

Ratio of each principal particular

(b) The influence degree of principal particulars on the total engine mass (12 B 350 type)
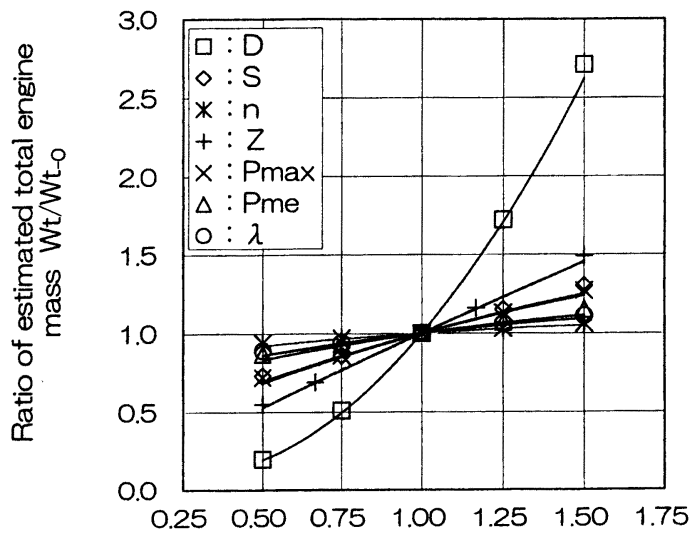

Ratio of each principal particular

(c) The influence degree of principal particulars on the total engine mass ( $12 \mathrm{C} 450$ type)

Fig. 1
リンダ数 $Z$, 最高圧力 $P_{\max }$, ピストン行程 $S$, 正味平 均有効圧力 $P_{m e}$, 連かん比 $\lambda$, 回転数 $n$ の順になって いることがわかる.ここで, 機関出力の増加を図る場 合には, 次の式 $(5)$ に示すようにその二乗に比例して 出力増加に影響するシリンダ内径 $D$ を増加すること が一番手っ取り早い方法になるが, 反面で機関総質量 はシリンダ内径 $D$ の 2.3 2.4 乗程度に比例して大き くなる傾向を伴うこと, また, 出力増加には比例的な 影響度をもつピストン行程 $S$, 正味平均有効圧力 $P_{m e}$, および回転数 $n$ などは機関総質量には $0.2 \sim 0.5$ 乗程 度にしか影響せず, 出力増大には有利であることなど が定量的に理解できる.

$$
\begin{aligned}
L_{e} & =Z \cdot P_{m e}(\pi / 4) D^{2} \cdot S(2 n / \mu) \\
& \times 10^{6} /(60 \times 1000) \cdots \ldots \ldots \ldots . .
\end{aligned}
$$

ここに,

$$
L_{e}: \text { 機関出力 }(\mathrm{kW})
$$

$Z:$ シリンダ数

$P_{m e}:$ 正味平均有効圧力 $(\mathrm{MPa})$

$D$ : シリンダ内径 $(\mathrm{m})$

$S:$ ピストン行程 $(\mathrm{m})$

$n:$ 回転数 $(\mathrm{rpm})$

$\mu:$ 係数 (四サイクル機関の場合 $\mu=4$ )

$3 \cdot 3 \cdot 2$ 出力当たり質量におよぼす主要目の影響度

図 2 と表 5 から, 各主要目を増加した場合に出力当 たり質量の増加につながる主要目と, かえって出力当 たり質量の減少につながる主要目の二つのグループが 存在することが明白である.すなわち, 前者のグルー プには影響度の大きいものから並べて最高圧力 $P_{\max }$, シリンダ内径 $D$, 連かん比入があり, 後者のグループ にはこれも影響度の大きいものから並べて回転数 $n$, 正味平均有効圧力 $P_{m e}$, ピストン行程 $S$, シリンダ数 $Z$ がある.これらのうち, 後者のグループに属する主 要目はいずれも前記の式 ( 5 ) から明らかなようにその 値を増すことによって機関出力を増加させながら, 同 時に出力当たり質量は減少させることが可能になるわ けで,このことは機関の出力当たり質量の軽量化, ひ いては製造コストの低減対策にもつながる極めて重要 な設計指針を示唆していると思われる.

ちなみに，これまでの永年にわたる一般的な機関開 発の経過をみると, 高過給化による正味平均有効圧力 の増加の傾向が顕著である，その根底にあるねらいは 機関のピストン行程容積当たり出力の増加にあったと 思われるが, 結果的には前述した理由により正味平均 有効圧力の増加によって機関の出力当たり質量の低減 に寄与していたことは興味深い.ここで, 回転数 $n$ の 影響度は顕著ではあるが, 一般的には機関の回転数は 


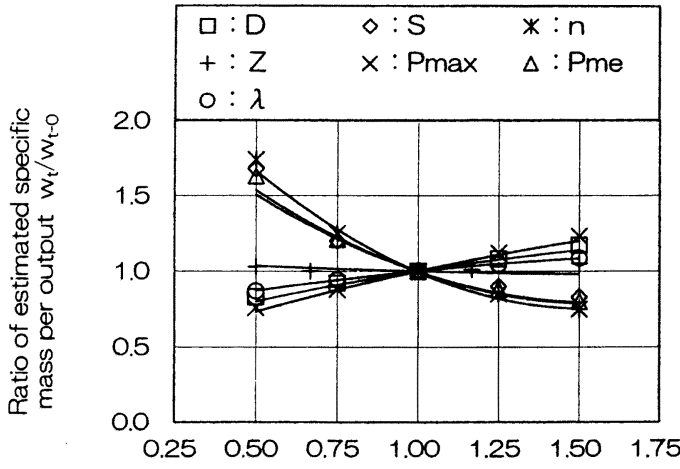

Ratio of each principal particular

(a) The influence degree of principal particulars on the specific mass per output (12 A 250 type)

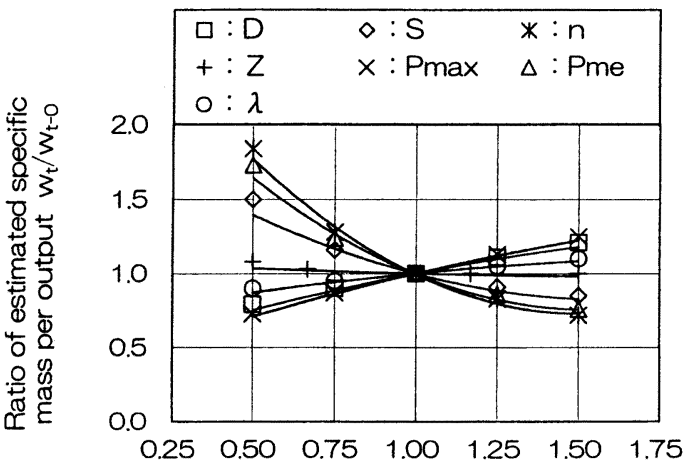

Ratio of each principal particular

(b) The influence degree of principal particulars on the specific mass per output (12 B 350 type)

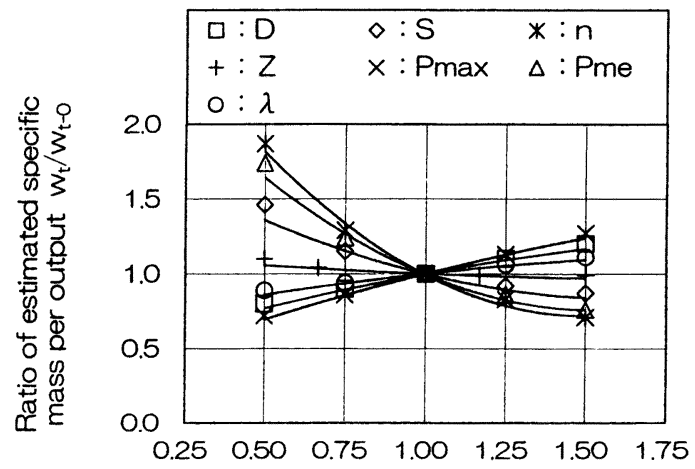

Ratio of each principal particular

(c) The influence degree of principal particulars on the specific mass per output (12 C 450 type)

Fig. 2

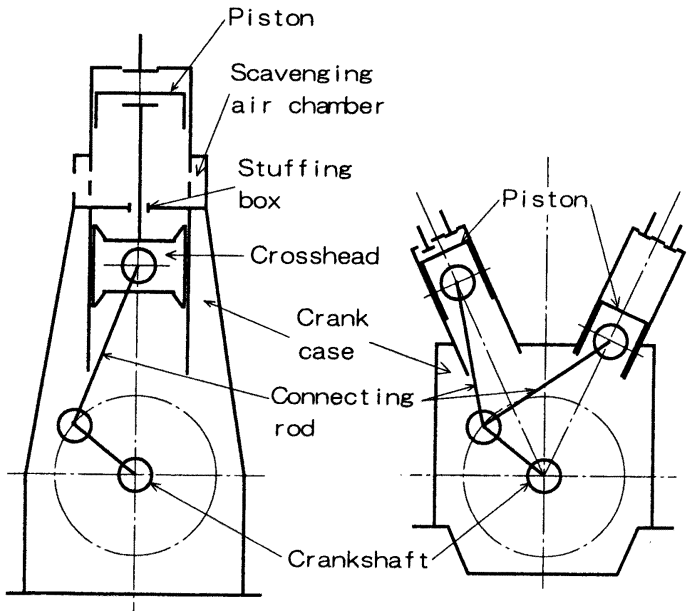

(a) Crosshead type

(b) Trunk-piston V type

Fig. 3 Rough structural figures of crosshead type and trunk-piston $\mathrm{V}$ type engines

例えば発電機の駆動などその使用目的によって制約さ れることが多く, また, 信頼性確保の点で平均ピスト ン速度からの制限もあるので，選定の自由度が狭く出 力当たり質量を低減させる目的のために使用される機 会は少なかったようである。

また，この出力当たり質量の低減効果については, 前述の機関総質量におよぼす影響度が比較的小さな, 具体的には式 (1) と表 4 に示した指数関数の乗べき数 が 1 より小さい主要目で, また同時に機関出力の算出 式である式 ( 5 )に含まれる主要目は回転数 $n$, 正味平 均有効圧力 $P_{m e}$, ピストン行程 $S$, シリンダ数 $Z$ の 4 項目であり，いずれも機関出力におよぼす影響度は一 乗に比例するので, 機関総質量を機関出力で除して求 める出力当たり質量におよぼすこれらの影響度は，指 数関数の乗べき数で示すといずれも負の值になるわけ で, このように考えるとこれらの影響度の傾向を理解 しやすい.

\section{$3 \cdot 4$ 二サイクル低速クロスヘッド形ディーゼル機}

\section{関の機関質量におよぼす主要目の影響度との比較}

著者らがかつて行った同様な考え方に基づく二サイク ル低速クロスヘッド形ディーゼル機関の機関質量に扔 よぼす主要目の影響度の解析結果について ${ }^{(2)(3)}$, 今回 実施した四サイクル中速 V 形ディーゼル機関の質量 におよぼす主要目の影響度の解析結果と比較するため に表 4 および表 5 に付記して示す. 表 4,5 から次の ことがわかる.なお，これらの二機種の機関を区別し て簡単に示すために, 前者を低速機関, 後者を中速機 関と略称する。 


\section{$3 \cdot 4 ・ 1$ 機関総質量におよぼす主要目の影響度}

両者の機関の影響度を総体的にみると, ピストン行 程 $S$ とシリンダ内径 $D$ に顕著な差が認められるが, その他の值はほぼ同程度である。なかでも中速機関の ピストン行程 $S$ につては, その影響度が約半減し ている.これは機関の構造が中速機関の場合はトラン クピストン形であり，低速機関の場合はクロスヘッド 形であることに起因するものと考えられる。すなわ ち,クロスヘッド形の構造は図 3 に示すように(4), ト ランクピストン形に比べるといわば二階建ての構造に なるため, 高さ方向の寸法におよぼすピストン行程 $S$ の影響度はほほ 2 倍に近い值になることは容易に理解 できる．他方，両者の機関ともに最も影響度が大きい シリンダ内径 $D$ については, 中速機関の場合がやや 大きな值を示している。この理由については低速機関 の場合は各シリンダが直列に配置されているのに対し て，中速機関の場合には V 形で並列に配置されてお り, シリンダ内径 $D$ とシリンダ数 $Z$ の積值の機関の 長手方向の寸法 $L$ に対する割合 $(L /(Z \cdot D))$ の值は低 速機関に比べてより小さくコンパクト化されているの で, 長手方向の寸法に対するシリンダ内径 $D$ の影響 度もそれだけ大きくなったものと考えられる。

$3 \cdot 4 \cdot 2$ 出力当たり質量におよぼす主要目の影響度 両機関の影響度を総合的にみると,この場合もシリ ンダ内往 $D$ とピストン行程 $S$ に顕著な差があり, そ のほかはほぼ同程度のオーダにあることがわかる．シ リンダ内径 $D$ とピストン行程 $S$ が機関出力におよぼ す影響度は前記の式( 5 ) から明らかなように, Dの二 乗と $S$ の一乗に比例する. 他方，低速機関の場合に は表 4 から明らかなように機関総質量におよぼす影響 度も同様に $D$ の二乗と $S$ の一乗に比例することを示 している. 出力当たり質量におよぼす主要目の影響度 は, 機関総質量におよぼす影響度を機関出力におよぼ す影響度で除して求めるわけであるから, 低速機関の 場合これらの影響度がいずれも同程度であるために， お互いに相殺されてシリンダ内径 $D$ とピストン行程 $S$ が出力当たり質量におよぼす影響度はともに消隇 していることを示している. 中速機関の場合の機関総 質量におよぼすシリンダ内径 $D$ の影響度は表 5 から 明らかなように低速機関に比べてやや大きく，ピスト ン行程 $S$ のそれは約半隇している. したがって, 出 力当たり質量におよぼすこれらの影響度も, 低速機関 の場合と大きく異なった結果になっていることが理解 できる.このことは中速機関の場合にはピストン行程 $S$ を増加すること(いわゆるロングストローク化)に よって, 前述したように正味平均有効圧力 $P_{m e}$ に近い
程度の影響度で機関の出力を増加しながら同時に出力 当たり質量も低減できるという, 機関の計画者にとっ てはなはだ都合がよく, 極めて重要な計画指針を示唆 しているといえる，なお，このような場合にはロング ストローク化による性能におよぼす影響について, 別 途検討する必要があるのはいうまでもない.

\section{4. 機関質量簡易予測式の構築と検証}

機関の計画者にとって少々近似的ではあっても機関 質量を概括的に容易に予測できる式があれば，新規機 関開発の場合に, 本式を用いて最初に行うべき主要目 の選定作業を効率的に，かつ的確に進めることができ る. 3 章で示した主要目の機関質量におよぼす影響度 解析の結果から, 主要目比の変化量が基準とするモデ ル機関の当該主要目から士50\%程度の範囲内にあれ ば，表 4 および表 5 で示した指数関数の乗べき数の形 でその機関質量におよぼす影響度を近似できることが わかったので, 基準とするモデル機関の質量にこれら の各主要目の影響度を積算する形で, 機関総質量 $W_{t}$ と出力当たり質量 $w_{t}$ を容易に予測できる機関質量簡 易予測式を導いた。なお,この簡易予測式を使用する 場合には，厳密には基準として適用するモデル機関と 同様の設計思想で開発する機関の質量を予測すること になり,このことは任意のモデル機関の大形化や出力 を増加したシリーズ機関を開発する場合などに特に有 効的に使用できることを意味する.

$4 \cdot 1$ 機関総質量簡易予測式の構築 次に機関総 質量簡易予測式の基本式を示す.

$$
W_{t}=W_{t-o} \cdot I\left(W_{t}\right) \cdot
$$

$$
\text { ここに, }
$$

$W_{t}$ : 予測する機関総質量 $(\mathrm{t})$

$W_{t-o}$ : 基準とするモデル機関の機関総質量 $(\mathrm{t})$ $I\left(W_{t}\right)$ : 機関総質量評価指数 添字

$$
o \text { : 基準とするモデル機関 }
$$

を示す。

ここで, 機関総質量評価指数 $I\left(W_{t}\right)$ は次式で求める ことができる.

$$
\begin{aligned}
& I\left(W_{t}\right)=R(D)^{\alpha} \cdot R(S)^{\beta} \cdot R(n)^{\gamma} \\
& \quad \times R(Z)^{\delta} \cdot R\left(P_{\max }\right)^{\varepsilon} \cdot R\left(P_{m e}\right)^{\zeta} \cdot R(\lambda)^{\eta}
\end{aligned}
$$

ただし

$$
\begin{aligned}
& R(D)^{\alpha}=\left(D / D_{o}\right)^{\alpha}, R(S)^{\beta} \\
& \quad=\left(S / S_{o}\right)^{\beta}, \cdots, R(\lambda)^{\eta}=\left(\lambda / \lambda_{o}\right)^{\eta}
\end{aligned}
$$

ここに

$D$ ：シリンダ内径 $(\mathrm{mm})$

$S:$ ピストン行程 $(\mathrm{mm})$ 


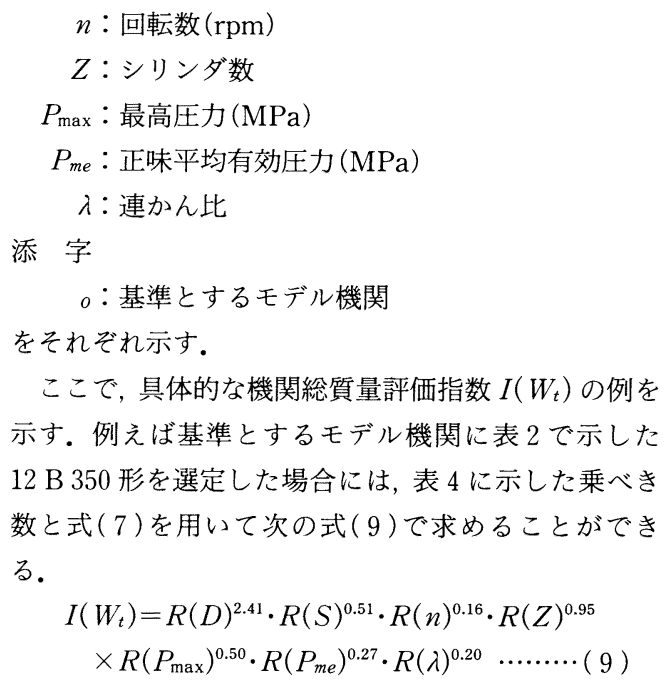

ここで, 具体的な機関総質量評価指数 $I\left(W_{t}\right)$ の例を 示す．例えば基準とするモデル機関に表 2 で示した 12 B 350 形を選定した場合には，表 4 に示した乗べき 数と式( 7 )を用いて次の式 (9)で求めることができ る.

$$
\begin{aligned}
& I\left(W_{t}\right)=R(D)^{2.41} \cdot R(S)^{0.51} \cdot R(n)^{0.16} \cdot R(Z)^{0.95} \\
& \quad \times R\left(P_{\max }\right)^{0.50} \cdot R\left(P_{\text {me }}\right)^{0.27} \cdot R(\lambda)^{0.20} \ldots \cdots \cdots \cdots(9)
\end{aligned}
$$

$4 \cdot 2$ 出力当たり質量簡易予測式 次に出力当た り質量簡易予測式の基本式を示す.

$$
w_{t}=w_{t-o} \cdot I\left(w_{t-o}\right)
$$

ここに,

$w_{t}$ : 予測する出力当たり質量 $(\mathrm{kg} / \mathrm{kW})$

$w_{t-o}$ : 基準とするモデル機関の出力当たり質量 $(\mathrm{kg} / \mathrm{kW})$

$I\left(w_{t-0}\right)$ : 出力当たり質量評価指数

添字

$$
o \text { : 基準とするモデル機関 }
$$

を示す.

ここで, 出力当たり質量評価指数は次式で求めるこ とができる。

$$
\begin{aligned}
& I\left(w_{t-o}\right)=R(D)^{\alpha^{\prime}} \cdot R(S)^{\beta^{\prime}} \cdot R(n)^{\gamma^{\prime}} \cdot R(Z)^{\delta^{\prime}} \\
& \quad \times R\left(P_{\max }\right)^{\varepsilon^{\prime}} \cdot R\left(P_{m e}\right)^{\xi^{\prime}} \cdot R(\lambda)^{\eta^{\prime}} \cdots \cdots \cdots \cdots \cdots
\end{aligned}
$$

ただし，

$$
\begin{aligned}
& R(D)^{\alpha^{\prime}}=\left(D / D_{o}\right)^{\alpha^{\prime}}, R(S)^{\beta^{\prime}} \\
& \quad=\left(S / S_{o}\right)^{\beta^{\prime}}, \cdots, R(\lambda)^{\eta^{\prime}}=\left(\lambda / \lambda_{o}\right)^{\eta^{\prime}}
\end{aligned}
$$

ここに,

$$
\begin{aligned}
& D: \text { シリンダ内径 }(\mathrm{mm}) \\
& S: \text { ピストン行程 }(\mathrm{mm}) \\
& n: \text { 回転数 }(\mathrm{rpm}) \\
& Z: \text { シリンダ数 }
\end{aligned}
$$

$P_{\max }:$ 最高圧力 $(\mathrm{MPa})$

$P_{m e}:$ 正味平均有劾圧力 $(\mathrm{MPa})$

$$
\lambda: \text { 連かん比 }
$$

添字

$$
o \text { : 基準とするモデル機関 }
$$

をそれぞれ示す。

ここで, 具体的な出力当たり質量評価指数 $I\left(w_{t-o}\right)$ の例を示す．例えば基準機関に表 2 に示したモデル機 関 12 B 350 形を選定した場合には，表 5 に示した乗べ

\begin{tabular}{|c|c|c|c|c|c|c|c|c|}
\hline \multicolumn{3}{|l|}{ Model engines } & \multicolumn{2}{|c|}{$12 \mathrm{~A} 250 \rightarrow 12 \mathrm{~A} 350$} & \multicolumn{2}{|c|}{$12 \mathrm{~B} 350 \rightarrow 128450$} & \multicolumn{2}{|c|}{$12 \mathrm{C} 450 \rightarrow 12 \mathrm{C} 550$} \\
\hline Cylinder bore & D & $\mathrm{mm}$ & 250 & 350 & 350 & 450 & 450 & 550 \\
\hline Piston stroke & $\mathrm{S}$ & $\mathrm{mm}$ & 320 & 448 & 410 & 527 & 590 & 721 \\
\hline Engine speed & $n$ & $\mathrm{rpm}$ & 1,000 & 714 & 750 & 583 & 500 & 409 \\
\hline Number of cylinders & Z & & 12 & 12 & 12 & 12 & 12 & 12 \\
\hline Max cylinder Pressure & $P \max$ & $\mathrm{MPa}$ & 18.0 & 18.0 & 18.0 & 18.0 & 18.0 & 18.0 \\
\hline Brake mean effect. Pressure & Pme & $\mathrm{MPa}$ & 2.45 & 2.45 & 2.45 & 2.45 & 2.45 & 2.45 \\
\hline Ratio ${ }^{* 1}$ & $\lambda$ & & 4.5 & 4.5 & 4.5 & 4.5 & 4.5 & 4.5 \\
\hline Engine output & Le & $\mathrm{kW}$ & 3.850 & 7,540 & 7,250 & 11,972 & 11,500 & 17,165 \\
\hline $\begin{array}{l}\text { Estimated engine } \\
\text { total mass } * 2\end{array}$ & Wt & $\mathrm{t}$ & 28.9 & $\begin{array}{r}66.9 \\
(1.0)\end{array}$ & 76.6 & $\begin{array}{r}150,8 \\
(1.0) \\
\end{array}$ & 150.9 & $\begin{array}{r}263.8 \\
(1.0) \\
\end{array}$ \\
\hline $\begin{array}{l}\text { Estimated engine } \\
\text { total mass } * 3\end{array}$ & $W t^{\prime}$ & $\mathrm{t}$ & - & $\begin{array}{l}66.3 \\
(0.991)\end{array}$ & - & $\begin{array}{c}153.2 \\
(1.016)\end{array}$ & - & $\begin{array}{l}265.2 \\
(1.005)\end{array}$ \\
\hline $\begin{array}{l}\text { Estimated specific } \\
\text { mass per output }{ }^{* 2}\end{array}$ & wt & $\mathrm{kg} / \mathrm{kW}$ & 7.51 & $\begin{array}{c}8.87 \\
(1.0)\end{array}$ & 10.57 & $\begin{array}{l}12.60 \\
(1.0)\end{array}$ & 13.12 & $\begin{array}{l}15.37 \\
(1.0)\end{array}$ \\
\hline $\begin{array}{l}\text { Estimated specific } \\
\text { mass per output }{ }^{* 3}\end{array}$ & $w t^{\prime}$ & $\mathrm{kg} / \mathrm{kW}$ & - & $\begin{array}{c}8.79 \\
(0.991)\end{array}$ & - & $\begin{array}{l}12.80 \\
(1.016)\end{array}$ & - & $\begin{array}{l}15.45 \\
(1.005) \\
\end{array}$ \\
\hline
\end{tabular}
き数と式(11)を用いて次の式(13)で求めることができ る.

$$
\begin{aligned}
& I\left(w_{t-o}\right)=R(D)^{0.41} \cdot R(S)^{-0.49} \cdot R(n)^{-0.84} \\
& \quad \times R(Z)^{-0.05} \cdot R\left(P_{\max }\right)^{0.50} \cdot R\left(P_{m e}\right)^{-0.73} \cdot R(\lambda)^{0.20}
\end{aligned}
$$

$4 \cdot 3$ 機関質量簡易予測式の精度の検証 予測式 の精度の検証を行う場合に，実際に機関を製造して確 かめることが望ましいが，現実的には困難であるので， 3 章で示したモデル機関 3 機種をそれぞれ基準機関と して取り上げ,これらとおのおの同一の設計思想をも つ仮想の機関を想定してそれらの機関総質量と出力当 たり質量を，前に著者らが開発した機関質量予測・評 価シミュレーション手法(1)を用いて算出した值と，機

Table 6 Verification of the simple estimating formulas for engine mass on the model engines in case enlarged size

(Note) $* 1$ : Ratio between connecting rod length and crank radius.

*2 : Estimated engine mass by the engine mass estimation and evaluation simulating method.

*3: Estimated engine mass by the simple estimating formulas for engine mass. 
関質量簡易予測式を用いて予測した値を比較して後者 の精度の検証を試みた。ここで仮想の機関を想定する 場合に，3機種のモデル機関とそれぞれ同一の設計思 想を保持するために, 各主要目について, シリンダ数 $Z$, 連かん比 $\lambda$, 最高圧力 $P_{\max }$, および正味平均有効 圧力 $P_{m e}$ は一定とし, シリンダ内径 $D$, ピストン行程 $S$, および回転数 $n$ をそれぞれ増加してモデル機関の 機関出力向上を図る新しいシリーズ機関を開発する場 合を想定した. 表 6 に検証の結果を示す. 機関総質量 と出力当たり質量のいずれもほぼ-1〜+2\%程度の差 で合致しており, 新しい機関を開発する際に多数の仕 様案から最適の主要目を取捨選択する場合などに効率 的に，かつ的確に活用することが可能であると考えら れる。

\section{5. むす び}

（1）新しい四サイクル中速 V 形ディーゼル機関 を開発する際には, 製造コストの目安にもなる機関総 質量や出力当たり質量の適切な目標値を初期計画の段 階から設定することが望ましい. ところで, この際に 並行して選定するいくつかの主要目にはこれらの機関 質量におよぼす影響が大きいものがあるので，これら の各主要目の影響度について解析を試みた。その結
果, 7 種類の主要目の影響度を指数関数の乗べき数の 形で定量的に，また明確に示すことができた。

（2）本影響度解析の結果を用いて，機関総質量や 出力当たり質量を容易に推定することができる機関質 量簡易予測式を構築することができた。

（3）これらの成果は新しい機関を開発する際の初 期計画の段階で, 適切な主要目を選定する場合に効率 的に，かつ的確に活用することができると考えられ る.

終わりに, 本研究に際して適切な助言と参考資料を 提供していただいた三菱重工業(株)課長 中野良治 氏，また有益な助言をいただいた長崎総合科学大学元 教授 恒屋礼二郎氏, 解析に協力された当時九州共立 大学卒業研究生の福原政之, 水上陽平, 椿寛和の諸君 に心から謝意を表す。

\section{文献}

（1）小山田哲也 - 和栗雄太郎 - 平山義則 - 生田宏, 機論, 68 $668, \mathrm{~B}(2002), 344-349$.

（2）小山田哲也・平山義則, 三菱重工技報, 25-5（1988），468472.

（3）小山田哲也 - 平山義則, 日本舶用機関学会誌, $24-4$ (1989), 79-85.

（4）日本機械学会編, 機械工学便覧, 内燃機関 B 7 編 (2000), B7-64. 